\title{
THE INTERMEDIATE GRADES AND DEPARTMENTALIZATION. II
}

\author{
DONALD DUSHANE \\ Superintendent of Schools, Clinton, Indiana \\ PART II \\ SECTION V. DEPARTMENTAL ORGANIZATION OF THE \\ INTERMEDIATE GRADES
}

The fight over the merits of the departmentalization of the seventh and eighth grades is almost a thing of the past. Its introduction experimentally in a large number of the schools of New York City, beginning about I900, gave the device a popularity which has led to its application rather extensively over the country. In I9I3, the United State Bureau of Education sent a questionnaire $^{\mathrm{x}}$ on departmental teaching in the grades to all cities having a population of 5,000 or over. Of $8 \mathrm{I} 3$ replies received, $46 \mathrm{I}$ showed some form of departmentalization in the grades, though very few cities reported this plan in operation below the seventh grade.

Fifteen years ago there was vigorous opposition to departmental work in the seventh and eighth grades, and many plausible arguments were made against it. It was claimed that the teachers would become narrow; the children would be overworked, would have no personal supervision; the program could not be arranged in accordance with the so-called laws of fatigue; disorderly conduct would be encouraged; correlation of subjects would be almost impossible. Experience has shown that if properly organized and safeguarded, departmental teaching in the seventh and eighth grades is not seriously open to criticism on any of the abovementioned grounds.

Possibly because the departmental organization was extensively and successfully applied only in the seventh and eighth grades in

${ }^{x}$ City School Circular No. 20, July I4, I9r3. 
New York City, and later only in these grades in numerous other cities, there is little vigorous opposition to it among schoolmen when it is confined to the seventh and eighth grades, but the proposition of departmentalizing the intermediate grades is not approved. The old stock arguments, so unsuccessfully used a decade ago against its introduction in the grammar grades, are again brought forward. It is further agreed that the work of the intermediate grades is largely to prepare the children for the grammar grades, that this work is well done, and that we should "let well enough alone"; the intermediate children need mothering more than expert teaching; these grades are not confronted with serious problems as are the grammar grades; young children would be confused by the number of teachers and the frequent shifting from one room to another; there are other problems much more important and more worthy of study and experimentation-for example, the junior high-school problem.

If departmental teaching stimulates the pupils of the seventh and eighth grades to greater effort, develops initiative, results in better teaching, greater interest, less repetition, less waste of time, makes possible the expansion and enrichment of the course of study, why will not these same ends be secured by departmentalizing the sixth grade, the fifth grade, or the fourth grade? Where is the point in the grades, if there is such a point, where the disadvantages outweigh the advantages? Are there fundamental reasons why the seventh grade is the lowest limit of worth-while departmentalization, or is this limitation based merely on inertia or submission to precedent?

If, as previously claimed in this paper, the intermediate grades are confronted with fundamental problems, and have an important work to accomplish, aside from preparing children for the grammar grades, then the foregoing questions are worth considering carefully. If the junior high-school movement is to succeed, the problem of the intermediate grades must be understood and a reorganization made which will result in more thorough teaching, a more purposeful course of study, and greater effort, initiative, and independence of thought from the children of these grades. 
SECTION VI. THE DEPARTMENTAL ORGANIZATION OF THE INTERMEDIATE GRADES OF MADISON, INDIANA

In January, I9I 2, after a careful consideration of the merits and demerits of departmental organization of the intermediate grades, the writer organized the $6 \mathrm{~B}, 5 \mathrm{~A}$, and $5 \mathrm{~B}$ grades of the Madison, Indiana, public schools departmentally, and in September, I9I2, extended this plan to the $4 \mathrm{~A}$ and ${ }_{4} \mathrm{~B}$ grades. Grades $6 \mathrm{~A},{ }_{7} \mathrm{~B},{ }_{7} \mathrm{~A}$, $8 \mathrm{~B}$, and $8 \mathrm{~A}$ were departmentalized in 1908 by Dr. W. A. Jessup, then superintendent at Madison; hence since September, I9I2, every grade above the third has been operated on this basis.

Madison is a city of between seven and eight thousand inhabitants, with a school enrolment of about I,300, which has not materially varied from this number for at least seven years. The school population is almost entirely American born, there being but three foreign-born children in school at the present time. There is a negro enrolment of about one hundred, for whom a separate school is maintained. The white children are divided between two schools until the middle of the sixth grade is reached, then they are sent to a grammar school for the work of Grades 6A, 7, and 8.

The semester enrolment for the last five years is shown in Table III.

TABLE III

\begin{tabular}{|c|c|c|c|c|c|c|}
\hline \multirow{2}{*}{ SEMESTER } & \multicolumn{5}{|c|}{ Grade } & \multirow{2}{*}{ TOTaL } \\
\hline & $4 B$ & ${ }_{4} \mathrm{~A}$ & $5 \mathrm{~B}$ & $5 \mathrm{~A}$ & $6 \mathrm{~B}$ & \\
\hline $\begin{array}{l}\text { First, } \text { IgII-I } \ldots \ldots \ldots \ldots \\
\text { Second, I9II-12 } \ldots \ldots \ldots \ldots\end{array}$ & $\begin{array}{l}75 \\
68\end{array}$ & $\begin{array}{l}69 \\
73\end{array}$ & $\begin{array}{l}62 \\
70\end{array}$ & $\begin{array}{l}42 \\
5^{2}\end{array}$ & $\begin{array}{l}52 \\
43\end{array}$ & $\begin{array}{l}300 \\
306\end{array}$ \\
\hline $\begin{array}{l}\text { First, rgr } 2-13 \ldots \ldots \ldots \ldots \\
\text { Second, rgr } 2-13 \ldots \ldots \ldots\end{array}$ & $\begin{array}{l}75 \\
67\end{array}$ & $\begin{array}{l}67 \\
68\end{array}$ & $\begin{array}{l}71 \\
65\end{array}$ & $\begin{array}{l}58 \\
58\end{array}$ & $\begin{array}{l}46 \\
53\end{array}$ & $\begin{array}{l}3 \text { I } 7 \\
3 \text { II }\end{array}$ \\
\hline $\begin{array}{l}\text { First, }{ }^{1913}{ }^{-14} \ldots \ldots \ldots \ldots \\
\text { Second, r9r } 3^{-14} \ldots \ldots \ldots \ldots\end{array}$ & $\begin{array}{l}49 \\
53\end{array}$ & $\begin{array}{l}58 \\
46\end{array}$ & $\begin{array}{l}70 \\
62\end{array}$ & $\begin{array}{l}53 \\
59\end{array}$ & $\begin{array}{l}48 \\
50\end{array}$ & $\begin{array}{l}278 \\
270\end{array}$ \\
\hline $\begin{array}{l}\text { First, rgr } 4-r_{5} \ldots \ldots \ldots \ldots \\
\text { Second, r9 }{ }^{4}-r_{5} \ldots \ldots \ldots \cdots\end{array}$ & $\begin{array}{l}63 \\
73\end{array}$ & $\begin{array}{l}47 \\
55\end{array}$ & $\begin{array}{l}47 \\
5 \mathrm{I}\end{array}$ & $\begin{array}{l}52 \\
41\end{array}$ & $\begin{array}{l}54 \\
48\end{array}$ & $\begin{array}{l}263 \\
268\end{array}$ \\
\hline 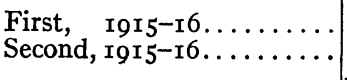 & $\begin{array}{l}70 \\
56 \\
\end{array}$ & $\begin{array}{l}62 \\
64\end{array}$ & $\begin{array}{l}64 \\
59\end{array}$ & $\begin{array}{l}4 \mathrm{I} \\
59\end{array}$ & $\begin{array}{l}36 \\
4 \mathrm{I}\end{array}$ & $\begin{array}{l}273 \\
279\end{array}$ \\
\hline Average enrolment..... & 64.9 & 60.9 & $62: I$ & $5^{1} .5$ & $47 . \mathrm{I}$ & 286.5 \\
\hline
\end{tabular}


The intermediate departmental teaching has been done by ten teachers in groups of five each. Following are the schedules of all teachers in one of the intermediate departments:

\section{DAILY PROGRAM, INTERMEDIATE DEPARTMENT}

Teacher of Language, Sponsor for 4 B Grade

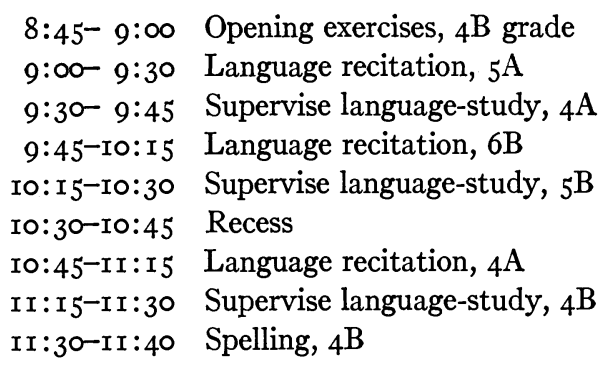

\section{Noon Intermission}

I:I5- I:45 Language recitation, $5 B$

$\mathrm{I}: 45-2: 00$ Supervise language-study, $5 \mathrm{~A}$ and $6 \mathrm{~B}$

2:00- 2:30 Language recitation, $4 \mathrm{~B}$

2:30- 2:45 Recess

2:45- 3:05 Music, $4 \mathrm{~B}$

3:05- 3:20 Writing, $4 \mathrm{~B}$

3:20- 3:40 Drawing, $4 \mathrm{~B}$

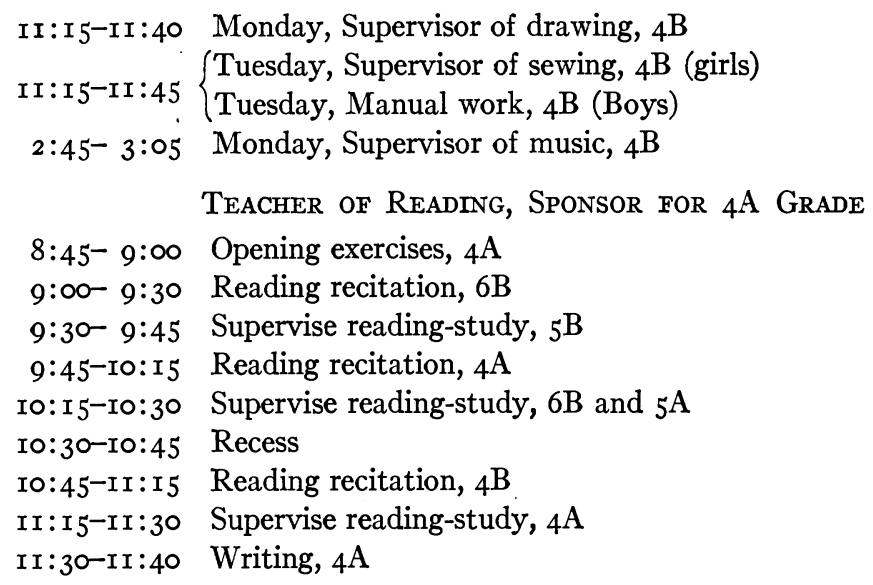

\section{Noon Intermission}

I:I5- I:45 Reading recitation, $5 \mathrm{~A}$

I: $45^{-}$- $2: 00$ Supervise reading-study, ${ }_{4} B$ 


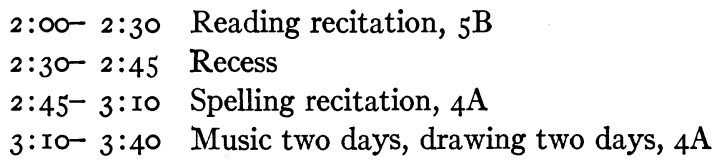

II:I5-II:40 $\left\{\begin{array}{l}\text { Monday, Supervisor of music, 4A } \\ \text { Wednesday, Supervisor of drawing, } 4 \mathrm{~A}\end{array}\right.$

II:05-II:40 $\left\{\begin{array}{l}\text { Tuesday, Supervisor of sewing, } 4 \mathrm{~A} \text { (girls) } \\ \text { Tuesday, Manual work, 4A (boys) }\end{array}\right.$

Teacher of Geography, Sponsor for 5 B Grade

8:45- 9:00 Opening exercises and miscellaneous work, ${ }_{5} \mathrm{~B}$

9:00- 9:30 Geography recitation, $4 \mathrm{~B}$

9:30- 9:45 Supervise geography-study, $5 \mathrm{~A}$ and $6 \mathrm{~B}$

9:45-10:I5 Geography recitation, $5 \mathrm{~A}$

I0: $15-10: 30$ Supervise geography-study, $4 \mathrm{~B}$

I0:30-10:45 Recess

I0:45-II:I5 Geography recitation, ${ }_{5} B$

II I I - II:30 Supervise geography-study, ${ }_{5} B$

$\mathrm{II}: 30-\mathrm{Ir}: 45$ Writing, $5 \mathrm{~B}$

\section{Noon Intermission}

I:I5- I:45 Geography recitation, 4A

$\mathrm{I}: 45-2: 00$ Supervise geography-study, $4 \mathrm{~A}$

2:00- 2:30 Geography recitation, 6B

2:30- 2:45 Recess

$2: 45-3: 00$ Spelling recitation, $5 \mathrm{~B}$

3:00- $3: 25$ Music or drawing, $5 \mathrm{~B}$

$3: 25-3: 35$ Spelling recitation, $5 \mathrm{~A}$

$3: 35^{-}-3: 50$ Physiology recitation, $5 \mathrm{~B}$ and $5 \mathrm{~A}$

$3: 00-3: 50\left\{\begin{array}{l}\text { Tuesday, Manual training, } 5 \mathrm{~B} \text { (boys) } \\ \text { Tuesday, Supervisor of sewing, } 5 \mathrm{~B} \text { (girls) }\end{array}\right.$

Teacher of Arithmetic, Sponsor for 5A and 6B Grades

8:45- 9:00 Opening exercises, $5 \mathrm{~A}$ and 6B

9:00- 9:30 Arithmetic recitation, $4 \mathrm{~A}$

9:30- 9:45 Supervise arithmetic-study, ${ }_{4} \mathrm{~B}$

9:45-IO: I5 Arithmetic recitation, $5^{B}$

I0: $15-$-10:30 Supervise arithmetic-study, $4 \mathrm{~A}$

I0:30-10:45 Recess

Io:45-II:I5 Arithmetic recitation, $6 \mathrm{~B}$

II:I5-II:30 Supervise arithmetic-study, $5 \mathrm{~A}$ and 6B

II:30-II:45 Writing, $5 \mathrm{~A}$ and 6B 


\section{Noon Intermission}

I:I5- I:45 Arithmetic recitation, $4 B$

I:45- 2:00 Supervise arithmetic-study, ${ }_{5} \mathrm{~B}$

2:00- 2:30 Supervise arithmetic-study, $5 \mathrm{~A}$

2:30- 2:45 Recess

2:45- 3:00 Supervise spelling-study, $5 \mathrm{~A}$ and $6 \mathrm{~B}$

$3: 00-3: 12$ Spelling recitation, $5 \mathrm{~A}$

$3: 12-3: 25$ Spelling recitation, 6B

$3: 25-3: 50$ Music or drawing, $5 \mathrm{~A}$ and $6 \mathrm{~B}$

$3: 00-3: 50\left\{\begin{array}{l}\text { Tuesday, Manual training for boys, } 5 \mathrm{~A} \text { and } 6 \mathrm{~B} \\ \text { Tuesday, Supervisor of sewing for girls, } 5 \mathrm{~A} \text { and } 6 \mathrm{~B}\end{array}\right.$

Teacher of History, Supervising Principal

9:00- 9:30 History recitation, $5 \mathrm{~B}$

9:45-10: 15 History recitation, $4 \mathrm{~B}$

IO: $45^{-I I}$ : I 5 History recitation, $5 \mathrm{~A}$

$\mathrm{I}: \mathrm{I5}-\mathrm{I}: 45$ History recitation, $6 \mathrm{~B}$

2:00- 2:30 History recitation, $4 \mathrm{~A}$

(Free time is devoted to supervision and other duties of Principal.)

Each teacher is sponsor for one group of pupils. They have their home seats in her room, have their opening exercises there, study and recite such subjects as spelling and writing under her supervision, are accountable to her for tardiness and absence, have class plays and entertainments under her charge. That the children have a feeling of direct responsibility to and interest in their home-room teacher is indicated by the answers to numerous apparently casual inquiries made of children in the intermediate department. There is no indication that the children have the feeling that they do not belong anywhere, or that there is no one particularly interested in their welfare.

Each child has daily recitations with five teachers in the following subjects: reading, arithmetic, language, geography, and history. He goes to the geography room to recite geography, the readingroom to recite reading, and likewise in the remaining subjects. The justification of this procedure is to provide frequent and needed physical relaxation, to avoid constant shifting of maps, books, and other equipment from one room to another, and to permit each teacher to plan her seat and board work with the least confusion 
and waste of effort. The study-periods for each subject are supervised by the teacher of that subject, in order that she may be able to give individual help and encouragement to those found in need of it during the recitation period. All study-periods are in the children's home study-rooms, where they can have access to their dictionaries, texts, and school supplies.

As the purpose of the first three grades is largely a preparation for the work of the intermediate grades, each intermediate teacher virtually introduces each child to her special subject and has entire charge of the development of that subject for a two-and-ahalf-year period. This not only fixes the entire responsibility on her for the acquirements of each child in her subject, but also gives her an opportunity thoroughly to understand the weaknesses, failures, idiosyncrasies, strong points, and needs of each child.

The five teachers of each departmental group hold frequent conferences which are of great benefit not only in securing a satisfactory correlation of subjects, but in solving problems of discipline and in obtaining a better understanding of needs, aptitudes, and home conditions of the children.

As far as possible, the interests and aptitudes of the teachers were considered in assigning the main subjects to be taught, and the plan was freely and critically discussed with each teacher before departmentalization was instituted.

\section{SECTION VII. REPORT OF DEPARTMENTAL TEACHERS}

In the spring of I9I6, a questionnaire on departmental teaching was sent to the ten intermediate departmental teachers of Madison. In order to secure frank answers, it was requested that the questions be answered without consultation, the desire for frank answers was emphasized, and there was no space for signatures on the blanks. Following are the questions and typical answers.

I. What are your objections, if any, to the departmental plan?

The prevailing answer was "None." Two teachers objected to their inability to alter the program for the purpose of securing more time for difficult lessons. A third teacher made the following answer: "None for the children's sake. In some subjects, the teacher's field is narrow."

2. In what respects is it better than the old plan of organization? 
Following is a summary of the answers in order of frequency:

a) Teachers do better work, 9 .

b) Pupils are benefited by contact with several personalities, 4 .

c) Work can be better organized when covering a two-and-a-half-year period, 3 .

d) The moving from room to room aids discipline, 3 .

e) More time for individual work with children, 2.

f) Permits longer recitation periods, 2.

g) Pupils are thrown on their own resources more than under the old plan, I.

h) Prevents the confusion and loss of time incident to a semi-annual change of children, $\mathrm{I}$.

i) The children make more progress, $\mathrm{I}$.

j) The children cover more ground in the departmental subjects, I.

$k$ ) Gives the teacher a better knowledge of the ability of each pupil, which enables her to work for the pupils' best interests more intelligently, $\mathrm{I}$.

l) Work can be more thoroughly studied and recitations more carefully planned and outlined, $\mathrm{I}$.

$m$ ) Teacher has opportunity to specialize, I.

n) Makes supervised study-periods possible, $\mathrm{I}$.

3. What, if any, effect has this plan had on the number of failures?

Ten report fewer failures.

4. How do the children progress under the system, compared with the other plan?

a) Children do more work, 6 .

b) There has been improvement in ability to study, 4 .

c) Better discipline, 3 .

d) More independent thinking by the pupils, $\mathrm{I}$.

e) More initiative shown by pupils, $\mathrm{I}$.

f) Self-control is better developed, I.

g) Work is more thorough, $\mathrm{r}$.

5. Do you feel that you can do better and more effective teaching under the old plan than under the new? State reasons.

Ten answered "No."

Summary of reasons:

"I can concentrate on one subject and thus do more effective work."

"I know exactly the work a class has covered and can anticipate the work to be done."

"I can plan and see the work in my subject as a whole and can better adapt it to the children's needs."

"Having children for several years gives me a better opportunity to correct their deficiencies."

"Under the old plan, the recitations were too short and there were too many subjects to prepare."

"Work is better organized and better taught." 
"I am better acquainted with the children."

"Because of the fewer subjects, aims and methods are better comprehended. More time to think of the children and their problems."

"Children seem more interested."

6. In your subject, how are the pupils doing compared with pupils of the same grade under the old plan?

All report better work.

7. How do the children like this plan?

Summary of answers:

"They like to pass from room to room and from teacher to teacher."

"There are fewer antagonisms between teacher and pupils."

"The children like this plan very much."

"The children like this plan because there is more activity connected with it."

8. Does it, or does it not, seem to be adapted to better meet their needs? Explain.

Summary of answers:

"It is better adapted to their needs."

"It gives the opportunity to both pupil and teacher to spend more time and energy on points which present special difficulty."

"Children get more individual attention and receive more efficient help in learning to study."

"Pupils are better understood and their abilities appreciated."

\section{SECTION VIII. RESULTS OF DEPARTMENTAL TEACHING IN INTERMEDIATE GRADES}

The following statement of the results of the departmental organization of the intermediate grades is based on careful observations made by the writer, on the opinions of departmental teachers, and on interviews with children of these grades.

r. The great reduction in the number of subjects to be taught by any one teacher and the consequent simplification of the program has enabled intermediate teachers to become specialists in the same sense that primary teachers and junior high-school teachers are specialists. The result has been a decided improvement in the teaching, in the organization of material, and in the methods of study of every departmental subject.

2. Each teacher is keenly aware of the daily comparison with the other four departmental teachers made by the children and is stimulated thereby to keep her work and discipline. up to a high standard. 
3. A two-and-a-half-year contact with each child and the entire responsibility for the work in a given subject for the same period is of immense benefit. It secures a better understanding of the character, disposition, ability, and home conditions of the children by the teacher, a better understanding of the character, ideals, and purposes of the teacher by the children. It prevents waste of time due to readjustments, lack of understanding, needless repetition of work, unnecessary reviews, and lack of knowledge of quality and amount of work covered in previous semesters. It definitely fixes the responsibility both for poor and for good work in a given subject. Under the conventional plan, the average city child enters a new room under a new teacher about every five months. If he is poorly taught, his teacher can with easy conscience ascribe his lack of progress to the poor teaching in the previous room. The duties of such a teacher are so numerous and the time allotted is so short that a teacher is fortunate if she has caught a clear vision of the needs and abilities of the individuals in her class before they are hurried on and thirty or forty new unknowns are brought in to replace the old. Public attention has not been sufficiently attracted to the waste due to short-lived contact between pupils and teacher and to the complexities of the grade teacher's program.

4. Supervised study-periods are made possible, which enables teachers to give individual help where it is needed and to prevent the formation of bad study-habits. We hear frequently of the need of supervised study in the high school, but if study were properly instituted and directed in the grades, there would be no such high-school problem.

5. The teachers are better pleased with their work and have a better understanding of their problems.

6. This plan makes possible the introduction of vocational work without disrupting the program or wasting the time of regular teachers.

7. The comparative immaturity of third-grade children and the small number of subjects to be taught make departmentalization of that grade unnecessary and inadvisable. Children of the fourth grade are able to work efficiently with departmental teachers. A further advantage of including the fourth grade is that the teacher 
of history, for example, can justly be held responsible for the historical attainments of all pupils completing the intermediate grades. For these reasons and because of the notable expansion of the course of study at this point, and because here first noticeably appears the beginning of what the writer believes to be a distinct period of mental development, departmental work was started in the fourth grade.

8. The moving of the classes from room to room breaks up the usual schoolroom monotony and affords a frequent normal outlet for physical energy.

TABLE IV

\begin{tabular}{|c|c|c|c|c|c|c|}
\hline & 4B & $4 \mathrm{~A}$ & $5 \mathrm{~B}$ & $5 \mathrm{~A}$ & $6 \mathrm{~B}$ & Total \\
\hline 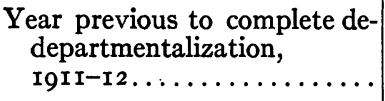 & II & I4 & I8 & Io & 8 & $6 I$ \\
\hline $\begin{array}{l}\text { First year of departmental- } \\
\text { ization, r912-13 } \ldots \ldots \ldots \ldots \ldots\end{array}$ & I7 & I9 & I7 & 9 & 3 & 65 \\
\hline Second year, r913-14.... & Io & 7 & I7 & 8 & I2 & 54 \\
\hline Third year, I9I4-I5 $\ldots \ldots \ldots$ & I4 & I & 7 & $\circ$ & $\mathbf{I}$ & 23 \\
\hline Fourth year, 19 I $5-16 \ldots$ & 12 & I 2 & I 2 & 9 & 5 & 50 \\
\hline
\end{tabular}

9. Among five teachers, every child is likely to find at least one who understands him, and, because of the frequent conferences among the teachers, is likely to be better appreciated and understood by all of his teachers. It is a fact that under the one-teacher plan children often withdraw because of lack of interest in, or because of dislike for, the teacher in charge of them. The bad effect of an unsympathetic or incapable teacher is minimized by the departmental plan.

ro. Under this plan, the course of study has a greater content value, and is more logically and thoroughly developed. In any given subject the work is carried on for several years without change of purpose or shifting of emphasis.

I I. There has been a decrease in the number of failures. This is indicated by the replies of the teachers shown above and by the statement of semester failures in these grades for the last five years given in Table IV. This table shows an increase of failures 
during the first year of complete departmentalization and a decrease of from to to 60 per cent in the three succeeding years.

r2. The plan seems suited to the needs and capabilities of intermediate-grade children.

I3. It offers a partial solution of the problem which must be solved before the junior high school can be justified, namely, the making of the work of the first six grades sufficiently extensive and purposeful to cover the worth-while material of the present eightyear course.

In organizing the intermediate grades departmentally, the following rules should be observed if the best results are to be obtained:

I. Every child should have a home room and a teacher in charge to whom he is directly responsible.

2. There should not be over one hundred and fifty pupils in a departmental group.

3. There should not be more than six teachers nor less than three in each department.

4. A pupil should have the same teacher for at least a two-year period.

5. The teachers should have a thorough knowledge of the possible benefits and defects of the plan, and should be willing to give departmentalization a fair trial, before the reorganization is attempted. held.

6. Frequent conferences of departmental teachers should be

7. The method of supervising study-periods should be carefully worked out.

8. As far as possible, subjects should be assigned to teachers in accordance with their interests and aptitudes.

9. The children should go to the various recitation rooms for recitations instead of the teachers being shifted. 